УДК 342.95

DOI https:/ / doi.org/10.32837/yuv.v0i5.2012

\author{
Є. Діденко, \\ кандидат юридичних наук, \\ доцент кафедри права \\ Академії рекреаційних технологій і права
}

\title{
ВІДНОСИНИ УКРАЇНИ ТА МІЖНАРОДНОЇ ОРГАНІЗАЦІї КРИМІНАЛЬНОЇ ПОЛІЦІї (ІНТЕРПОЛУ)
}

Одним із значних досягнень європейського інтеграційного процесу стало формування простору без внутрішніх кордонів із вільним переміщенням товарів, послуг, капіталів і осіб. За таких умов традиційні моделі організації роботи органів правопорядку є недосконалими, а ефективне гарантування безпеки на розглядуваному просторі є справою не лише окремих держав - членів європейського товариства, а й Європейського Союзу та міжнародного співтовариства загалом.

У такому контексті міжнародна спільнота визнає динамічний i всебічний розвиток транснаціональної злочинності як проблему, що несе небезпеку для людства. 3 огляду на це постає необхідність у системному об’єднанні зусиль держав та міжнародних організацій щодо вдосконалення форм взаємодії правоохоронних органів щодо розшуку осіб, які вчинили кримінальне правопорушення.

Вказане повною мірою стосується й України з моменту набуття нею своєї незалежності.

Інтеграція України в європейське співтовариство, інтенсифікація міжнародного співробітництва в усіх сферах суспільного життя, зокрема й у напрямі протидії організованій злочинності, одним із головних завдань визначають розроблення дієвих механізмів здійснення міжнародної взаємодії у сфері кримінальної юстиції. Сучасний рівень організованої зло- чинності, ऑї професійний і організований характер, а також набуття нею транскордонних і транснаціональних форм зумовлюють необхідність консолідації зусиль правоохоронних органів різних держав у вжитті спільних заходів, спрямованих на протистояння цьому антисуспільному явищу [1, с. 133-137].

Інтерпол як провідна міжнародна організація, завдяки свої унікальній структурі, правовій базі та технічному оснащенню здійснює ефективну та раціональну координацію міжнародного поліцейського співробітництва.

Офіційною датою створення Інтерполу є 7 вересня 1923 р., коли під час проведення Міжнародного поліцейського конгресу в м. Відень (Австрійська Республіка) була заснована Міжнародна комісія кримінальної поліції (далі - МККП).

У 1956 р. у Відні на ювілейній 25-й сесії Генеральної асамблеї МККП ухвалений Статут Організації, у якому зазначено, що віднині Міжнародна комісія кримінальної поліції називатиметься Міжнародною організацією кримінальної поліції (далі MOKП) - Інтерполом, забезпечуватиме співробітництво поліцейських відомств на світовому рівні. До цього вплив Організації поширювався переважно на держави Європи [2, с. 30].

Інтерпол забезпечує співробітництво поліцейських відомств на світовому рівні. У 1989 р. штаб-квартиру 
Інтерполу перенесено до м. Ліон (Франція) [3].

Від самого початку МОКП - Інтерпол розглядалась як неурядова організація. Однак згодом, після укладення спеціальної угоди про співробітництво 3 економічною та соціальною радою Організації Об’єднаних Націй (далі - ООН) у 1971 р. було визнано міжурядовий статус Інтерполу, який офіційно відображений у Резолюції Генеральної Асамблеї Організації Об'єднаних Націй від 15 жовтня 1996 р. Таким рішенням МОКП Інтерпол визнано спостерігачем на Генеральній Асамблеї ООН.

Метою МОКП $€$ «забезпечення розгалуженого співробітництва між зацікавленими органами кримінальної поліції в межах чинного національного законодавства країн - учасниць Інтерполу та суворій відповідності положенням Загальної декларації прав людини, створення і розвиток органів, необхідних для ефективної боротьби зі злочинністю». Натепер до складу Організації входять 186 держав, що дає підстави розглядати Інтерпол як одну з найчисельніших міжнародних організацій - глобального інституту співпраці поліцейських відомств країн світу.

Структурна МОКП - Інтерполе передбачає наявність пленарного дорадчого органу - Генеральної Асамблеї, виборного дорадчого органу Виконавчого комітету, адміністративно-виконавчого органу, що постійно діє, - Генерального секретаріату, національних центральних бюро Інтерполу, якими виступають уповноважені країнами-членами правоохоронні органи. Крім того, з наукових питань Організація може звертатись до радників, які призначаються Виконавчим комітетом строком на три роки та виконують суто консультативні функціі.

Основні напрями діяльності Інтерполу такі: «1) кримінальна реєстрація. Із цією метою ведеться алфавітна картотека всіх відомих міжнародних злочинців і осіб, підозрюваних у злочинній діяльності, картотека словесного портрета злочинців, де викладені відомості про зовнішність злочинців, картотека документів (паспорти, посвідчення водія тощо), картотека злочинів і способів їх здійснення, картотека нарізної ручної вогнепальної зброї всіх країн світу й інші; 2) міжнародний розшук злочинців, підозрюваних у скоєнні міжнародних злочинів, осіб, зниклих безвісти, викрадених цінностей та інших об'єктів злочинних посягань. У разі затримання злочинця за дипломатичними і іншими каналами проводяться переговори про його видачу (екстрадиціі) державі, на території якої скоєно злочин або громадянином якої він є. У практиці Інтерполу розрізняють три види розшуку: звичайний, терміновий і змішаний; 3) міжнародний розшук осіб, що пропали безвісти. У випадках, коли національний розшук не приніс успіху і коли зібрані докази того, що розшукувана особа покинула межі держави - ініціатора розшуку, на неї Генеральним секретаріатом видається «синій циркуляр», у якому наводяться фотографія розшукуваного, опис зовнішності і вказується номер досьє, за яким Генеральний секретаріат збирає документи про його розшук; 4) міжнародний розшук викрадених цінностей (автомобілі та інші транспортні засоби, твори мистецтва (картини, скульптури, антикваріат, інші музейні експонати), археологічні цінності, зброя тощо)» [3].

Діяльність Інтерполу обмежується лише реєстрацією злочинців і міжнародним розшуком. Співробітники Інтерполу не виконують жодних поліцейських функцій. Вони поділяються на дві категоріі: офіцерський корпус (від лейтенанта до майора), що виконує оперативно-аналітичні функції під час оброблення інформаціiі про злочини, виконує клопотання про надання інформації з картотек, і обслуговуючий персонал - секретарі, друкарки, телефоністи, оператори 
картотек, фотографи, перекладачі, бібліотечні працівники й інші.

Включення України до Інтерполу відбулося 4 листопада 1992 р. на 61-й сесії Генеральної Асамблеї Інтерполу в м. Дакар (Сенегал). 25 березня 1993 р. постановою Кабінету Міністрів України № 220 створене Національне центральне бюро Інтерполу в Україні. Зазначеним документом також затверджено положення про Національне центральне бюро (далі НЦБ) Інтерполу в Україні, відповідно до якого Бюро представляє Україну в МОКП - Інтерполі та $€$ центром координації взаємодії правоохоронних органів України 3 компетентними органами закордонних держав у питаннях боротьби із транснаціональною злочинністю. Уряд визначив, що як НЦБ Інтерполу в Україні виступає Міністерство внутрішніх справ [4].

Робота Бюро здійснюється безпосередньо відповідно до вимог постанови Кабінету Міністрів України від 25 березня 1993 р. № 220 «Про Національне центральне бюро Інтерполу». Зокрема, до 18 вересня 2020 р. була чинною Інструкція про порядок використання правоохоронними органами можливостей Національного центрального бюро Інтерполу в Україні у відверненні, розкритті та розслідуванні злочинів, яка передбачала порядок використання правоохоронними органами України можливостей НЦБ Інтерполу в Україні для співробітництва 3 Генеральним секретаріатом Інтерполу та правоохоронними органами закордонних держав під час діяльності, пов'язаної з попередженням, розкриттям та розслідуванням злочинів, що мають транснаціональний характер або виходять за межі України. Нині формується новий порядок такої співпраці, із включенням до переліку нових органів та розширенням повноважень.

Основні завдання Укрбюро Інтерполу такі: «координація діяльності правоохоронних органів країни в боротьбі зі злочинністю, що має транснаціональний характер або виходить за межі країни; забезпечення взаємодіі з Генеральним секретаріатом та відповідними органами держав - членів Інтерполу в боротьбі зі злочинністю; оцінка рівня поширення в Україні злочинності, що має транснаціональний характер, і загрози злочинної діяльності громадян України за кордоном» [5, с. 556].

Укрбюро Інтерполу взаємодіє із правоохоронними органами, центральними і місцевими органами державної влади України, керівними органами i структурними підрозділами Інтерполу, правоохоронними органами закордонних держав. Укрбюро Інтерполу отримує інформацію від правоохоронних органів, центральних і місцевих органів державної виконавчої влади України з питань, що входять до його компетенції, та надає їм отриману за лінією Інтерполу інформацію безплатно.

Робочий апарат Укрбюро Інтерполу $€$ самостійним структурним підрозділом центрального апарату Міністерства внутрішніх справ (далі - MBC), його очолює керівник, який призначається наказом МBC. Структура і штати робочого апарату Укрбюро Інтерполу затверджуються міністром внутрішніх справ.

Утворення Укрбюро Інтерполу засвідчило якісно новий етап нашої держави у здійсненні міжнародної протидії організованій злочинності.

Відбуваються постійний обмін оперативною інформацією в рамках кримінальних проваджень, участь у спільних заходах із розслідування щодо широкого кола злочинів, а також аналіз оперативної інформаціï як важливого вектора взаємодії між Національною поліцією України і МОКП - Інтерпол у боротьбі із загальнокримінальною злочинністю. Серед основних векторів взаємодіï сфера кібер- і наркозлочинності, доступу України до телекомунікаційної системи I/24-7 за технологією 
FIND i недопущення зловживань Росією інструментами Інтерполу.

Телекомунікаційна система Інтерполу I/24-7 (Інтерпол 24 години на добу 7 днів на тиждень) являє собою захищену від стороннього доступу мережу з обмеженим колом користувачів, що за своєю глобальністю не має аналогів у світі та $є$ ефективним інструментом міжнародного співробітництва правоохоронних органів. Завдяки впровадженню цієї системи всі підрозділи Національної поліції будуть мати доступ до баз даних Інтерполу.

Натепер Україна перебуває в десятці лідерів за якістю й інтенсивністю співробітництва 3 Інтерполом: останніми роками кількість запитів до баз даних зросла майже у 370 разів і натепер становить 34,7 млн. Кожну секунду Інтерпол обробляє 3 українські запити.

Протягом 2017 р. Національною поліцією України вжито заходів щодо впровадження проєкту "Socta" системи збору, обробки й узагальнення інформації. За ініціативи консультативної місії ЄC (EUAM) створено міжвідомчу робочу групу, до складу якої увійшли представники Ради національної безпеки і оборони України, МВС України та компетентних підрозділів Національної поліції України.

За результатами діяльності міжвідомчої робочої групи напрацьовано стратегію впровадження методології "Socta", обговорений порядок створення системи збору інформації, іiі обробки й узагальнення, 3 використанням сучасної аналітичної методології, а також методологічний посібник із "Socta" $з$ урахуванням індикаторів, властивих Україні [6].

Результатом розглядуваної вище співпраці є дієві справи вітчизняних правоохоронних органів та Інтерполу. Ще у 2012 р. співробітники Служби безпеки України (далі - СБУ) у межах кримінального провадження затримали мешканця Одещини на пункті пропуску «Нові Трояни» під час спроби контрабандного переправлення в Україну кілограма особливо небезпечного наркотичного засобу героїну. «Товар» зловмисник приховав у спеціально обладнаному сховищі власного автомобіля. Проте, скориставшись рішенням суду щодо зміни міри запобіжного заходу із тримання під вартою на підписку про невиїзд, фігурант провадження незаконно перетнув держкордон та переховувався в іноземних країнах.

Для розшуку зловмисника представники української спецслужби звернулися до закордонних партнерів, зокрема за лінією Інтерполу, та передали відповідні матеріали.

Так, у липні 2019 р. під час спільної спецоперації правоохоронці Німеччини й Інтерполу ідентифікували та затримали наркоділка під час використання документів, отриманих на інші анкетні дані, 3 метою переховування від правосуддя. За матеріалами СБУ, затриманого повернуто на територію України [7].

Проте варто зазначити, що нормативно-правова база, яка регулює його статус, потребує вдосконалення. На часі необхідність усунення правових прогалин в українському законодавстві в частині використання доказів, отриманих на території нашої держави (зокрема, з допомогою працівників НЦБ Інтерполу), що заважає механізму конструктивного міжнародного співробітництва.

Потребує сучасного підходу відповідна методика підбору та розстановки кадрів. На нашу думку, доцільно призначати виконавцями працівників, які володіють необхідною кваліфікацією, компетенцією та належною інформацією, з досконалим знанням однієї 3 іноземних мов.

Досліджувані питання свідчать, що практичне значення міжнародного співробітництва України в галузі боротьби із кримінальними злочинами стрімко набуває національного характеру. У сучасних умовах таке

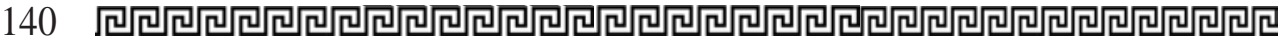


співробітництво має особливе значення. Необхідні постійне вдосконалення й оновлення форм і засобів взаємодії органів кримінальної поліції країн-співробітників в рамках Інтерполу, створення ефективної оперативної інтегрованої бази даних, удосконалення засобів доступу та передачі інформаціі.

Поширення транснаціональних зв'язків злочинних угруповань різних країн потребують плідної міжнародної співпраці правоохоронних органів. Діяльність Укрбюро Інтерполу важлива для правоохоронних України не лише з погляду ефективності поточного моменту, але і щодо перспектив розвитку. Якість роботи Бюро - один із найважливіших чинників міжнародного авторитету правоохоронних органів України.

Незважаючи на відносно короткий період своєї діяльності, Національне центральне бюро Інтерполу України проявило себе як дієва структура MBC, яка постійно нарощує свої сили. Інтенсивний обмін оперативною інформацією в рамках Інтерполу супроводжується оптимізацією цього процесу з українського боку.

Для впровадження більш ефективних механізмів протидії організованій злочинності юридичним установам важливо розглядати питання про подальшу розробку міжнародних документів, базуючись на позитивному досвіді і результатах, досягнутих у процесі розроблення і здійснення чинних двосторонніх та багатосторонніх угод із широким колом учасників. Розроблення таких міжнародних документів під егідою Інтерполу сприятиме досягненню більшого рівня погодження національних законодавств у питаннях, які стосуються введення кримінальних покарань за участь в організованій транснаціональній злочинній діяльності, ужиття більш ефективних заходів у галузі кримінального правосуддя та розширення використання механізмів взаємної допомоги і видачі злочинців.
У статmі досліджуються положення щодо співпраці Міжнародної організації кримінальної поліиіï - Iнтерполу та правоохоронних органів України. Iнтеграція Украіни у європейське співтовариство, активне міжнародне співробітництво в усіх сферах суспільного життя, зокрема й у напрямі протидіі організованій злочинності, є одним із головних завдань розроблення дієвих механізмів здійснення міннародної взаємодіi у сфері кримінальної юстицї. Сучасний рівень організованої злочинності, iï професійний та організований характер, а також набуття нею транскордонних $i$ транснаціональних форм зумовлюють необхідність консолідації зусиль правоохоронних органів різних держав у здійсненні спільних заходів, спрямованих на протистояння цььому антисуспільному явищу

Iнтерпол забезпечує співробітництво поліцейських відомств на світовому рівні. Мета Iнтерполу - «забезпечення розгалуженого співробітництва між зацікавленими органами кримінальної поліції в межах чинного національного законодавства країн - учаснищь Iнтерполу mа суворій відповідності положенням Загальної декларациї прав людини, створення $і$ розвиток органів, необхідних для ефективної боротьби зі злочинністю».

Основні завдання Укрбюро Iнтерполу такі: координація діяльності правоохоронних органів країни у боротьбі зі злочинністю, щзо має транснаціональний характер або виходить за межі країни; забезпечення взаємодіі з Генеральним секретаріатом та відповідними органами держав - членів Iнтерполу в боротьбі зі злочинністю; оцінка рівня поширення в Украӥні злочинності, щз має транснаціональний характер, $i$ загрози злочинної діяльності громадян України за кордоном». 
Досліджувані питання свідчать, що практичне значення міннародного співробітництва України в галузі боротьби із кримінальними злочинами стрімко набувае національного характеру. У сучасних умовах таке співробітництво мае особливе значення. Необхідні постійне вдосконалення й оновлення форм і засобів взаємодії органів кримінальної поліції країн-співробітників в рамках Iнтерполу, створення ефективної оперативної інтегрованої бази даних, удосконалення засобів доступу та передачі інформації.

Ключові слова: міжнародне співробітництво, Інтерпол, кримінальна юстиція, кримінальна поліція, протидія злочинності, міжнародний розшук.

Didenko E. Relations between Ukraine and International Criminal Police Organization

The article examines the provisions on cooperation between the International Criminal Police Organization - Interpol and law enforcement agencies of Ukraine. Ukraine's integration into the European community, active international cooperation in all spheres of public life, including in the direction of combating organized crime, is one of the main tasks of developing effective mechanisms for international cooperation in the field of criminal justice. The current level of organized crime, its professional and organized nature, as well as its acquisition of cross-border and transnational forms necessitates the consolidation of efforts of law enforcement agencies of different states in the implementation of joint measures to combat this anti-social phenomenon.

Interpol ensures the cooperation of police agencies at the global level. The purpose of the IOCP - Interpol is: "to ensure extensive cooperation between the criminal police concerned within the current national legislation of the Interpol member states and strict compliance with the provisions of the Universal Declaration of Human Rights, establishment and development of bodies necessary to combat crime".

The main tasks of the UkrBureau of Interpol are: coordination of the activities of the country's law enforcement agencies in the fight against crime that has a transnational character or goes beyond the country; ensuring liaison with the General Secretariat and relevant bodies of the Member States of Interpol in the fight against crime; assessment of the level of transnational crime in Ukraine and the threat of criminal activity of Ukrainian citizens abroad.

The researched issues show that the practical significance of Ukraine's international cooperation in the fight against criminal offenses is rapidly gaining national character. In modern conditions, such cooperation is of particular importance. It is necessary to constantly improve and update the forms and means of interaction of criminal police bodies of the participating countries within the framework of Interpol, to create an effective operational integrated database, to improve the means of access and transmission of information.

Key words: international cooperation, Interpol, criminal justice, criminal police, fight against crime, international search.

\section{Література}

1. Барко В.I., Величко В.В. Психологічний зміст $i$ особливості професійної правоохоронної діяльності пращівників Iнтерполу МВС України. Право і безпека. 2015. № 3. С. 133-137.

2. Гаврилюк B.I., Дубина В.I., Данилюк М.П. Актуальні аспекти міжнародного співробітнищтва органів внутрішніх справ України на напрямі протидіі торгівлі людьми / за ред. В.І. Гаврилюк. Київ : Цифра, 2007. 420 c. 


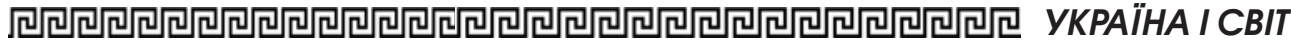

3. Стражинський В.С., Стражинський С.В., Хотенецьь П.В. Інтерпол. Міжнародна організація кримінальної поліиії : навчальний посібник. Харків : Бурун Книга, 2006. 112 с.

4. Положення про Національне центральне бюро Iнтерполу, зі змінами $i$ доповненнями від 16 грудня 2017 р. Відомості Верховної Ради України.

5. Говійко Є.А. Завдання національного иентрального бюро Iнтерпол. Митна справа. Львів, 2011. № 5. С. 555-560.
6. Арсен Аваков зустрівся з генсекретарем Iнтерполу Юргеном. Урядовий nортал. URL: https://www.kmu.gov.ua/ пешь / 250445173 (дата звернення: 30.09.2020).

7. СБУ та Інтерпол затримали контрабандиста героїну, який переховувався 8 років. URL: https:// espreso.to/news/2019/07/25/sbu_ ta_interpol_zatrymaly_kontrabandysta_ geroyinu_yakyy_perekhovuvavsya_8_rokiv (дата звернення: 30.09.2020). 